\title{
KEMAMPUAN MENCERITAKAN KEMBALI ISI CERPEN KETIKA SEBUAH MIMPI DIPAHAMI KARYAAL-KAUSARZ SABANI PESERTA DIDIK KELAS VIII SMP NEGERI 26 BANJARMASIN
}

\author{
THE ABILITY TO REVEAL THE CONTENT OF THE MIRROR WHEN A DREAM IS \\ UNDERSTANDED BY THE WORK OF AL-KAUSARZ SABANI STUDENTS CLASS VIII \\ OF SMP NEGERI 26 BANJARMASIN
}

\author{
Annisyah Maulida; Fatah Yasin; Dewi Alfianti \\ Program Studi Pendidikan Bahasa dan Sastra Indonesia \\ FKIP Universitas Lambung Mangkurat \\ maulidanisa456@gmail.com
}

\begin{abstract}
Abstrak
Penelitian ini bertujuan untuk mendeskripsikan bagaimana kemampuan menceritakan kembali isi cerpen peserta didik kelas VIII SMPN 26 Banjarmasin. Tarigan menyatakan bahwa menulis ialah menurunkan atau melukiskan lambang-lambang grafik yang menggambarkan suatu bahasa yang di pahami oleh seseorang. Metode dan Pendekatan yang digunakan dalam penelitian ini adalah deskriptif kuantitatif. Sampel penelitian, yaitu 60 peserta didik kelas VIII SMPN 26 Banjarmasin. Berdasarkan kemampuan menceritakan isi cerpen pada kelas VIII-B 50\% peserta didik "mampu" dan 50\% peserta didik "sangat mampu" dalam menceritakan isi cerpen. Sedangkan di kelas VIII-E $47 \%$ peserta didik "mampu" dan 53\% peserta didik "sangat mampu" dalam menceritakan isi cerpen. Secara keseluruhan gabungan kelas VIII-B dan VIII-E 52\% peserta didik dinyatakan "mampu" dalam menceritakan isi cerpen dan $48 \%$ peserta didik dinyatakan "sangat mampu" dalam menceritakan isi cerpen.
\end{abstract}

Kata kunci: menulis, kemampuan menulis, cerpen

Abstract

This study aims to describe how the ability to retell the contents of the short story of class VIII students of 26 Public High School Banjarmasin. Tarigan states that writing is to reduce or describe graphic symbols that describe a language understood by someone. The methods and approaches used in this study are quantitative descriptive. The research sample was 60 students of class VIII of Public High School 26 Banjarmasin. Based on the ability to tell the contents of the short story in class VIII-B 50\% of students "capable" and 50\% of students "very capable" in telling the contents of the short story. Whereas in class VIII-E $47 \%$ of students were "capable" and 53\% of students were "very capable" in telling the contents of the short story.Overall the combined classes VIII-B and VIII-E 52\% of students were declared "capable" of telling the contents of the short story and $48 \%$ of students were declared "very capable" in telling the contents of the short story.

Keyword: writing, writing skills, short stories 


\section{Pendahuluan}

Pembelajaran selalu bergerak mengikuti perkembangan ilmu pengetahuan dan teknologi. Kurikulum yang KTSP yang sudah diimplementasikan sejak 2006 kini berubah menjadi Kurikulum 2013 yang mencakup kompetensi sikap, pengetahuan, dan keterampilan. Mengubah keadaan seseorang dari tidak tahu menjadi tahu.

Pembelajaran adalah salah satu membelajarkan peserta didik untuk dapat menggunakan asas maupun teori belajar dan pendidikan. Keterampilan menulis juga dapat dilatih pada peserta didik secara optimal. Dengan menulis seseorang mampu berusaha untuk mengungkapkan pikiran dan perasaan kepada orang lain. Peneliti dalam memilih SMPN 26 Banjarmasin sebagai lokasi penelitian karena masih rendahnya kete-rampilan menceritakan isi cerpen dan sekolah tersebut merupakan sekolah rujukan yang ada di Banjarmasin. Sekolah ini salah satu dari sekolah yang telah mengimplementasikan Kurikulum 2013. Pemerolehan data yang didapatkan dengan bukti yang sebenar-benarnya dapat dilihat dengan berdasarkan kemampuan peserta didik dan standar nilai sekolah yang sangat baik. Pemilihan kemampuan menceritakan kembali isi cerpen dilatar belakangi oleh rendahnya kemampuan menulis ini dalam menceritakan kembali isi cerpen pada pelajaran Bahasa Indonesia peserta didik kelas VIII-B dan VIII-E. Namun, pada umumnya dapat dilihat pembelajaran keterampilan menulis di SMP 26 Negeri Banjarmasin kurang maksimal, guru-guru cenderung lebih dominan pada pembelajaran teori kebahasaan. Maka dari itu keterampilan menulis belum tercapai secara optimal, terbukti peserta didik masih takut untuk mengemukakan pendapat, malu bertanya, kurang percaya diri dalam berkomunikasi, serta sulit untuk mengungkapkan kembali isi cerita dan sebagainya. Sehingga cerita yang disampaikan guru tidak dapat diceritakan kembali sepenuhnya oleh peserta didik. Adanya keinginan untuk, mengetahui bagaimana kemampuan peserta didik dalam menceritakan kembali isi cerpen. Penelitian ini mengenai kemampuan menceritakan kembali isi cerpen sebelumnya sudah pernah dilakukan oleh Dewan Syafutra dan Siti Samhati dalam jurnal ini yang berjudul Pembelajaran Menulis Cerita Pendek Siswa Kelas XI SMA Penelitian mengenai kemampuan menceritakan kembali isi cerpen. Sebelumnya Yuni Setiarini dalam jurnal Upaya Meningkatkan Kemampuan Menganalisis Unsur Intrinsik Pada Cerpen Melalui Media Audiovisual. Kedua jurnal ini pada dasarnya sama, karena yang didapat dari jurnal ini juga mengarah pada kemampuan menulis. Perbedaannya terletak pada metode penelitiannya. Karya sastra yang akan penulis teliti adalah karya sastra berupa cerpen yang berjudul ketika sebuah mimpidi pahami yang membahas bagaimana peserta didik dalam menulis menceritakan kembali isi cerpen.

\section{Metode Penelitian}

Penelitian yang berjudul kemampuan peserta didik menceritakan kembali isi cerpen yang telah di baca, ini menggunakan metode penelitian kuantitatif dan pendekatan deskriptif.

\section{Populasi dan Sampel Penelitian}

Populasi penelitian ini adalah seluruh peserta didik kelas VIII tahun pelajaran 2018/2019 yaitu sebanyak 180 orang, dengan perincian jumlah peserta didik di setiap kelas VIII adalah 30.

\section{Teknik Pengumpulan Data}

Teknik yang digunakan untuk mengumpulkan data berupa angket dan tes. 


\section{Instrumen Penelitian}

Instrumenini dalam penelitian kemampuan menceritakan kembali isi cerpen berupa bentuk soal 8 essai. Tes kemampuan menceritakan atau dalam teks cerpen berdasarkan menceritakan kembali isi cerpenl, serta membuat rubrik penilaian kemampuan menceritakan kembali isi cerpen. Instrumen yang digunakan dalam penelitian ini adalah contoh cerpen karya alkausarz sabani yang berjudul sebuah mimpi dipahami.

\section{Teknik Analisis Data}

Analisis data yang diperoleh dalam penelitian ini menggunakan analisis statistik deskriptif. Statistik deskriptif dapat digunakan untuk menghitung skor rerata, simpangan baku, varian, maksimum, minimum, sum, range, kurtosis, dan skewness (Ghozali, 2009:19). Skor rerata (mean) kemudian dikategorikan sehingga diperoleh frekuensi persentase yang diharapkan. Data yang telah dikumpul dianalisis melalui langkahlangkah sebagai berikut: (1) mengidentifikasi hasil jawaban dan tulisan peserta didik, (2) menentukan skor tes penguasaan dan tes berbicara Bahasa Indonesia dalam teks cerpen, berdasarkan aspek yang diteliti, (3) penentuan nilai mentah menjadi skor, (4) mencari nilai rata-rata dari data yang telah diperoleh, (5) mengkoversikan hasil kemampuan rata-rata berdasarkan dari penilaian, (6) menentukan klasifikasi kemampuan yang menampilkan histogram (grafik batang) dari hasil olahan data, (7) menyimpulkan hasil analisis data.

\section{Hasil Penelitian Dan Pembahasan}

Hasil dari penelitian kemampuan menceritakan kembali isi cerpen dalam teks cerpen peserta didik kelas VIII SMPN 26
Banjarmasin diambil dari sampel yang telah ditentukan. Hasil tersebut diambil secara berkala waktu, sampel kelas VIII-B diambil pada tanggal 7 November 2018 dan sampel kelas VIII-E diambil pada tanggal 8 November 2018. Hasil penelitian berupa data tersebut dideskripsikan berikut ini.

\section{Deskripsi Data}

Penelitian ini memperoleh satu jenis data, yaitu tes kemampuan menceritakan kembali dalam teks cerpen. Didapatkan data yang telah dijawab oleh peserta didik dengan berdasarkan rubrik penilaian di setiap tes. Tes tersebut dilaksanakan dalam tataran waktu $2 \times 40$ menit, peserta didik menjawab sesuai pengetahuan dalam teks cerpen. Berdasarkan pada tes yang telah dilaksanakan, adapun hasil yang telah didapatkan dari populasi, yaitu 60 kemudian terbagi menjadi: kelas VIII-B sebanyak 30 orang dan VIII-E sebanyak 30 orang. Dalam penelitian kemampuan menceritakan isi cerpen ini, peserta didik diberikan tes esai, sebanyak 8 soal dengan kriteria yang telah ditentukan. Tes adalah kelanjutan dari tes penguasaan, di dalam soal tersebut terdapat kesalahan menulis Bahasa Indonesia sehingga peserta didik dilatih untuk memperbaiki kesalahan tersebut.

\section{Kemampuan Menceritakan Kembali Isi Cerpen Peserta Didik Kelas VIII-B}

Berdasarkan tes yang dilaksanakan didapatkan hasil dari populasi, yaitu sebanyak 30 orang. Soal esaai sebanyak 8 soal dengan kisi-kisi yang sesuai, mempunyai skor 5 dalam 1 soal sehingga skor maksimal adalah 40. Pelaksanaan tes ini berjalan dengan lancar dan jawaban yang diperoleh sesuai dengan kemampuan peserta didik. Skor yang tertinggi dalam tes menceritakan kembali isi cerpen, yaitu 87,5 
dan skor yang terendah dalam menceritakan kembali isi cerpen, yaitu 75 .

\section{Kemampuan Menceritakan Kembali Isi Cerpen Peserta Didik Kelas VIII-E}

Berdasarkan penelitian menggunakan tes esai, sebanyak 8 soal dengan kriteria yang telah ditentukan. Tes ini adalah kelanjutan dari tes penguasaan karena setelah pemahaman peserta didik diuji maka tes penerapan selanjutnya, untuk melatih peserta didik dalam menceritakan kembali isi cerpen dengan benar. Selain itu, di dalam soal tersebut terdapat kesalahan berdasarkan unsur intrinsik dan unsur ekstrinsik sehingga peserta didik dilatih untuk memperbaiki kesalahan tersebut. Pelaksanaan tes ini berjalan dengan lancar dan jawaban yang diperoleh sesuai dengan kemampuan peserta didik. Skor tertinggi dalam tes menceritakan kembali isi cerpen, yaitu 90 sedangkan skor terendah dalam menceritakan kembali isi cerpen, yaitu 70 .

\section{Kesalahan Menceritakan Kembali Isi Cerpen Berdasarkan Unsur Intrinsik dan Ekstrinsik}

Berdasarkan penelitian ini dalam kesalahan menceritakan kembali isi cerpen berupa hasil karangan cerpen berdasarkan unsur intrinsik dan ekstrinsik peserta didik, dengan memperhatikan rubrik penilaian, yaitu kemampuan menceritakan kembali isi cerpen. Sampel yang telah ditentukan adalah 60 orang, yang mengerjakan soal 4 kesalahan menceritakan kembali isi cerpen berdasarkan unsur intrinsik dan ekstrinsik hanya 53 orang. Kesalahan dari penelitian kemampuan menceritakan kembali isi cerpen berdasarkan unsur intrinsik dan ekstrinsik. Kemudian, dari kesalahan tersebut dideskripsikan sesuai dengan kategori kemampuan menceritakan kembali isi cerpen dan dirubah ke dalam bentuk persentase dengan menggunakan rumus $\mathrm{f} / \mathrm{n}$ x $100 \%$.

\section{Faktor-Faktor Yang Mempengaruhi Kkm Nilai 65 Pelajaran Bahasa Indonesia}

Pendapat (Syah, 2000) faktor-faktor yang mempengaruhi $\mathrm{kkm}$ nilai 65 pelajaran bahasa Indonesia berikut ini.

1) Peserta didik menganggap sepele mata pelajaran Bahasa Indonesia dibandingkan pelajaran eksakta lainnya.

2) Pembelajaran Bahasa Indonesia yang ditetapkan guru lebih cenderung model mengajar ceramah dan tanya jawab.

3) Kemampuan guru juga dalam pembelajaran terbatas dan strategi kurag tepat.

4) Sebagian besar peserta didik mengalami kesulitan dalam belajar.

5) Peserta didik dalam proses pembelajaran cenderung kurang memperhatikan penjelasan guru.

6) Rendahnya minat dan prestasi terhadap pelajaran Bahasa Indonesia.

\section{Analisis Data}

Analisis data dilakukan setelah skor peserta didik ditentukan menggunakan rubrik dan rentang nilai. Analisis data tes penguasaan dan kemampuan menceritakan kembali isi cerpen dilakukan untuk mengetahui rata-rata nilai keseluruhan peserta didik. Tes kesalahan kemampuan menceritakan kembali isi cerpen dilakukan untuk mendeskripsikan kesalahan unsur intrinsik dan ekstrinsik dalam teks cerpen. Analisis data dipaparkan, berikut ini.

\section{Kemampuan Menceritakan Kembali Isi Cerpen Berdasarkan Statistik}

Berdasarkan tabel di atas dapat diketahui bahwa kelas VIII-B memperoleh 533.1667 rerata untuk menentukan nilai rata-rata, 352.22319 standar deviasi, 
minimum (Xmin) sebesar 75.00 dalam menentukan nilai data statistik terkecil, maximum (Xmax) sebanyak 875.00 dalam menentukan nilai data statistik tertinggi. Kelas VIII-E memperoleh 339.3333 rerata untuk menentukan nilai rata-rata, 348.74586 standar deviasi, minimum (Xmin) sebesar 70.00 dalam menentukan nilai data statistik terkecil, maximum (Xmax) sebanyak 875.00 dalam menentukan nilai data statistik tertinggi.

\section{Hasil Kemampuan Menceritakan Kembali Isi Cerpen Kelas VIII-B}

Berdasarkan hasil yang diketahui bahwa persentase 50\% peserta didik SMPN 26 Banjarmasin kemampuan menceritakan kembali isi cerpen berada pada kategori mampu. 50\% peserta didik yang memiliki kemampuan kategori sangat mampu. Berdasarkan hasil dapat disimpulkan bahwa kecenderungan kemampuan menceritakan peserta didik berada pada ketegori sedang. Dengan demikian, dapat diketahui bahwa persentase kategori dari hasil kemampuan menceritakan kembali isi cerpen yang tertinggi adalah peserta didik dengan rentang nilai 70-79 yang termasuk dalam kategori "mampu”. Berdasarkan hasil yang telah diperoleh peserta didik menujukkan keaktifan sebanyaknya 15 peserta didik dari 30 peserta didik yang kurang aktif.

\section{Frekuensi Kemampuan Menceritakan Kembali Isi Cerpen Kelas VIII-B}

Kemampuan menceritakan kembali isi cerpen berdasarkan unsur intrinsik dan ekstrinsik memperoleh nilai 75 ada 3 peserta didik atau $10 \%$. Yang memperoleh nilai 80 ada 7 peserta didik atau 23,3\%. Yang memperoleh nilai 85 ada 1 peserta didik atau 33\%. Yang memperoleh nilai 77,5 ada 12 peserta didik atau 40\%. Yang memperoleh nilai 82,5 ada 6 peserta didik atau 20\%. Yang memperoleh 87,5 ada 1 peserta didik atau 33\%. Jadi nilai menceritakan kembali isi cerpen termasuk kategori mampu.

\section{Hasil Kemampuan Menceritakan Kembali Isi Cerpen Kelas VIII-E}

Berdasarkan hasil diketahui bahwa persentase $47 \%$ peserta didik SMPN 26 Banjarmasin kemampuan menceritakan kembali isi cerpen berada pada kategori mampu. Dan 53\% peserta didik yang memiliki kemampuan menceritakan kembali isi cerpen pada kategori sangat mampu. Dengan demikian, dapat diketahui bahwa persentase kategori dari hasil kemampuan menceritakan kembali isi cerpen yang memperoleh nilai tertinggi adalah peserta didik dengan rentang nilai 80-100 yang termasuk dalam kategori "sangat mampu”. Berdasarkan hasil dapat disimpulkan bahwa kecenderungan kemampuan menceritakan kembali isi cerpen peserta didik berada pada ketegori tinggi.

\section{Frekuensi Kemampuan Menceritakan Kembali Isi Cerpem Kelas VIII-E}

Kemampuan menceritakan kembali isi cerpen berdasarkan unsur intrinsik dan ekstrinsik memperoleh nilai 70 ada 1 peserta didik atau 33\%. Yang memperoleh nilai 75 ada 5 peserta didik atau $16,7 \%$. Yang memperoleh nilai 80 ada 11 peserta didik atau 36,7\%. Yang memperoleh nilai 90 ada 2 peserta didik atau 6,7\%. Yang memperoleh nilai 72,5 ada 2 peserta didik atau $6,7 \%$. Yang memperoleh 77,5 ada 5 peserta didik atau $16,7 \%$. Yang memperoleh nilai 82,5 ada 3 peserta didik atau 10\%. Yang memperoleh nilai 87,5 ada 1 peserta didik atau 33\%. Jadi nilai menceritakan kembali isi cerpen termasuk kategori sangat mampu. 


\section{Hasil Kemampuan Menceritakan Kembali Isi Cerpen Kelas VIII-B dan VIII-E}

Berdasarkan bagan di atas diketahui bahwa persentase $52 \%$ peserta didik SMPN 26 Banjarmasin kemampuan menceritakan berada pada kategori mampu. Tetapi 48\% peserta didik yang memiliki kemampuan menceritakan pada kategori sangat mampu. Dengan demikian, dapat diketahui bahwa persentase kategori dari hasil kemampuan menceritakan kembali isi cerpen yang tertinggi adalah peserta didik dengan rentang nilai 80-100 yang termasuk dalam kategori "sangat mampu". Berdasarkan hasil disimpulkan bahwa kecenderungan kemampuan menceritakan peserta didik berada pada ketegori sedang.

\section{Frekuensi Kemampuan Menceritakan Indonesia Kelas VIII-B Dan Kelas VIII-E}

Kemampuan menceritakan kembali isi cerpen berdasarkan unsur intrinsik dan ekstrinsik memperoleh nilai 70 ada 1 peserta didik atau $1,7 \%$. Yang memperoleh nilai 75 ada 8 peserta didik atau 13,3\%. Yang memperoleh nilai 80 ada 18 peserta didik atau 30\%. Yang memperoleh nilai 85 ada 1 peserta didik atau 1,7\%. Yang memperoleh nilai 90 ada 2 peserta didik atau 3,3\%. Yang memperoleh nilai 72,5 ada 2 peserta didik atau 3,3\%. Yang memperoleh nilai 77,5 ada 17 atau 28,3\%. Yang memperoleh nilai 82,5 ada 9 peserta didik atau 15\%. Yang memperoleh nilai 87,5 ada 2 atau 3,3\%. Jadi nilai menceritakan kembali isi cerpen termasuk kategori mampu.

\section{Hasil Kesalahan Kemampuan Menceritakan Kembali Isi Cerpen}

Kesalahan penelitian ini dalam kemampuan menceritakan kembali isi cerpen telah banyak ditemui, terutama dalam karangan peserta didik. Dengan demikian, hasil temuan penelitian ini adalah kesalahan menceritakan, 15,7\% , kesalahan tema 2,3\% kesalahan tokoh dan penokohan 11\%, kesalahan alur 16,6\%, kesalahan latar tempat,waktu, dan suasana 3,75\% kesalahan amanat dan 15,7\% kesalahan nilai moral $12 \%$. Dengan demikian, dapat dikatakan bahwa kesalahan terbanyak peserta didik dalam alur adalah 16,6\%.

\section{Simpulan}

Berdasarkan hasil penelitian yang telah dilaksanakan dapat disimpulkan kemampuan menceritakan kembali isi cerpen berikut ini.

1) Persentase kemampuan menceritakan isi cerpen kelas VIII-B SMPN 26 Banjarmasin, yaitu 50\% peserta didik yang "mampu" menceritakan kembali isi cerpen, 50\% peserta didik yang "sangat mampu" dalam menceritakan kembali isi cerpen. Dengan kategori kemampuan menceritakan isi cerpen ini “Mampu”.

2) Persentase kemampuan menceritakan kembali isi cerpen kelas VIII-E SMPN 26 Banjarmasin, yaitu $47 \%$ peserta didik yang dikategorikan "maтрu" menceritakan kembali isi cerpen, 53\% peserta didik yang "sangat mampu" dalam menceritakan isi cerpen. Dengan kategori dari kemampuan menceritakan isi cerpen ini "Sangat матрu”.

3) Persentase dari kesalahan kemampuan menceritakan isi cerpen pada peserta didik kelas VIII-B dan VIII-E sebesar kesalahan menceritakan kembali isi cerpen, $15,7 \%$, kesalahan tema 2,3\% kesalahan tokoh dan penokohan $11 \%$, kesalahanalur $16,6 \%$, kesalahan latar 3,75\% kesalahan amanat dan $15,7 \%$ kesalahan nilai moral $12 \%$. 
Kesalahan terbanyak terdapat pada alur adalah $16,6 \%$.

\section{Saran}

Berdasarkan hasil penelitian kemampuan peserta didik dalam menceritakan kembali isi cerpen yaitu berdasarkan unsur intrinsik dan ekstrinsik ketika sebuah mimpi dipahami karya Al-Kausarz Sabani ini, saran-saran yang disampaikan kepada pihak lain sebagai berikut ini.

1) Bagi guru Bahasa Indonesia SMP Negeri 26 Banjarmasin sebaiknya lebih menerapkan pembelajaran yang paling tepat, misalnya pembelajaran bercerita agar dilatih peserta didik untuk berbicara dengan baik dan lancar.

2) Bagi yang ingin meneliti mengenai kemampuan menceritakan kembali isi cerpen, seperti pada penelitian ini, sebaiknya perlu dilanjutkan aspek kemampuan berbahasa yang lainnya.

3) Meskipun peserta didik SMPN 26 Banjarmasin telah memiliki kemampuan yang cukup baik dalam kemampuan menceritakan kembali isi cerpen, tetapi pembinaan kemampuan berbahasa pada peserta didik sebaiknya tetap terus ditingkatkan.

\section{Daftar Rujukan}

Andriani.(2016). Peningkatan Kemampuan Menganalisis Unsur Instrinsik Dengan Model Inside Out Side Circle Siswa Kelas XI IPA SMA Negeri 1 Polw Ali Kabupaten Polewli Mandar. Pepatuzdu, 22-2

Bistok, Sirait. (1985). Pedoman KaranganMengarang. Jakarta: Pusat Pembinaan Dan Pengembangan Bahasa.

Cartig, Hago. (2017). Pembelajaran Menulis Cerita Pendek Siswa Kelas XI SMA
Muhammadiyah 2 Bandar Lampung. Pendidikan Bahasa dan Sastra, 5-8

Dalman.(2011).MenulisKaryallmiah.Bandar Lampung: PT Raja Grafindo Persada.

Dasnawatni, Tentri. (2017). Keefektifan Model Kooperatif Team Games Tournament Terhdaap Kemampuan Menemukan Unsur Intrinsik Cerpen Kelas IX SMP Negeri 2 Keera. Keguruan dan Ilmu Pendidikan, 9-12.

Henry, Tarigan, Guntur. (1982) . Menulis. Bandung: FKSS Bandung.

Iskandar. (2008). Metodologi Penelitian Pendidikan dan Sosial. Jakarta: Gaung Persada Press.

Keraf, G. (1980). Komposisi. Ende- Flores: Nusa Indah.

Kunandar. (2010). Teknik Mind Mapping Sebagai Upaya Untuk Meningkatkan Keterampilan Menulis Cerpen Pada Siswa SMP. Pendidikan Bahasa Dan Sastra Indonesia, 4-7.

Mahsun. (2014). Metode Penelitian Bahasa. Depok: PT Raja Grafindo Penrsada.

IKIP, Malang. (2010). Pedoman Penulisan Karya Ilmiah. Malang: Universitas Negeri Malang.

Mubaraq, Akhmad, Khusni. (2017). Keefektifan Pembelajaran Menulis Cerpen Dengan Model Sinetik Dan Model Kreatif- Produktif Pada Peserta Didik SMA Berdasarkan Tife Pemerolehan Informasi. Pendidikan Bahasa Dan Sastra Indonesia, 2-4.

Musaba, Zulkifli. Dan Siddik, Moh. (2017).

Dasar-DasarKeterampilan

Menulis. Yogyakarta:Aswaja

Pressindo.

Nugiyantoro.(2018). Peningkatan Keterampilan Menceritakan Kembali Isi Cerpen Dengan Menerapkan Strategi Pembelajaran Think Talk Write Pada Siswa SMP 1. Tabularasa, 26.

Nurgiyantoro, Burhan. ddk. (2000). Statistik Terapan Untuk Penelitian Ilmu-Ilmu 
Sosial.Yogyakarta: Gajah Mada University Press.

Pradotokusumo.(2005). Pengajian Sastra. Jakarta: PT Gramedia Pustaka Utama.

Ratna. (2016). Analisis Unsur Intrisik dan Ekstrinsik pada Kumpulan Cerpen PilihanKompas 2014 Serta Relevansinya Sebagai Media Pembelajaran Sastra di Sekolah Menengah Atas. Basastra, 184-186.

Saddhono, Kundharu, Slamet, S.Y. (2014). Pembelajaran Keterampilan Berbahasa. Yogyakarta: Graha Ilmu.

Setiarini, Yuni.(2015). Upaya Meningkatkan Kemampuan Menganalisis Unsur Intrinsik Pada Cerpen Melalui Media Audiovisual. Penelitian Tindakan Kelas, 3-5.

Sitepu, Rusmiaty. (2014). Upaya Meningkatkan Minat dan Prestasi Belajar Siswa Melalui Metode Cooperativ Script Mata Pelajaran Bahasa Indonesia Kelas VIII. Kependidikan,24-26.

Sugiyono.(2010). Metode Penelitian Pendidikan. Bandung: Alfabeta.

Syafi'ie. (1988). Retorika dalam Menulis. Jakarta: P2LPTK Depdikbud.

Syafutra, Dewan. (2017). Pembelajaran Menulis Cerita Pendek Siswa Kelas XI
SMA Muhammadiyah 2 Bandar Lampung. Pendidikan Bahasa dan Sastra Indonesia, 3-5.

Thahar. (2008). Upaya Meningkatkan Kemampuan Menganalisis Unsur Intrinsik Pada Cerpen Melalui Media Audivisual. Penelitian Tindakan Kelas, 1-2.

Umar, Husien. (2011). Metode Penelitian Untuk Skripsi dan Tesis Bisnis. Jakarta: Rajawali Pers.

Yulisna, Risa. (2013). Kontribusi Kemampuan Memahami Cerpen Terhadap Keterampilan Menulis Cerpen Siswa Kelas XI SMA Negeri 4 Padang Gramatikal, 3-6.

Yunarti, Netti. (2013). Peningkatan Kualitas Pembelajaran dan Kemampuan Menulis Cerita Pendek Dengan Menggunakan MetodePetaPikiran (MIND MAPPING) Pada Siswa Kelas IX A SMP Negeri 9 Pontianak. Pendidikan Bahasa dan Sastra. 2-3. 
